\title{
PALEOECOLOGIC ASPECTS OF ICHNOFABRICS (BIOGENIC SEDIMENTARY FABRICS) IN DEEP-SEA SEDIMENT
}

\author{
EKDALE, A. A., Dept. of Geology and Geophysics, University of Utah, \\ Salt Lake City, UT 84112-1183 U.S.A.
}

The paleoecology of deep-sea, benthic, macroinvertebrate communities is largely confined to the trace fossil record. While a few taxa have preservable hard parts, most of the deep-sea macrofauna are unpreservable as body fossils below the aragonite or calcite compensation depths. The ichnologic record provides important synecologic information regarding the behavioral diversity and endobenthic habitat partitioning of at least some community members.

The deep-sea trace fossil record is strongly influenced by sediment composition (biogenic calcite vs. terrigenous clay), sedimentation regime (pelagic vs. turbidite deposition) and bioturbation history (continuous vs. discontinuous burrowing). These influences are directly reflected in the ichnofabric, or biogenic sedimentary fabric.

Ichnofabrics of deep-sea sediments can shed light on the ecologic relationships of the infaunal community (trophic and tiering relationships), occupation of the sea floor by successive and different communities (deciphered from the different trace fossil suites in a composite ichnofabric), stability and firmness of the sedimentary substrate (revealed by burrow distinctness and deformation), interstitial oxygen conditions below the sea floor (determined from the abundance and preservation state of depositfeeding burrows, such as Chondrites and Zoophycos), and effects of bioturbation patterns on early diagenetic processes (differential cementation and mineralization).

The sedimentary habitat of the ancient deep-sea floor changes through time via compaction, dewatering, cementation and secondary mineralization. The benthos that inhabit this changing habitat likewise change according to their differing requirements for burrowing and endobenthic feeding. The resulting ichnofabric reflects a successive occupation of the sea floor by different types of organisms, ranging from shallow burrowers to deep burrowers to hard-substrate borers. Composite ichnofabrics thus can reveal a complex sequence of ecologic and diagenetic events.

The tiered structure of infaunal communities in late Cretaceous and early Tertiary shelf-sea chalks is well-known, and because of their pelagic depositional aspect, these situations provide good analogues in outcrop for truly deep-sea environments. In the European and North American chalks, deeply emplaced fodinichnia (Thalassinoides, Chondrites and Zoophycos) typically are superimposed upon shallowly emplaced fodinichnia and pascichnia (Planolites and Teichichnus). Tracks and trails of epifaunal animals certainly were produced at the sediment-water interface, but they are not preserved. Very similar ichnofabrics occur in late Cretaceous and early Tertiary pelagic carbonates in New Zealand, where composite ichnofabrics reveal at least five main phases of occupation of the substrate by burrowers and borers. Multiple generations of Thalassinoides include both burrows and borings, each produced at different stages in the development of a major regional unconformity.

Deep-sea pelagic deposits (in kilometers of water) represent a continuous accretion of the sea floor during sediment accumulation, accompanied by a continuous vertical shift of a tiered endobenthic community of burrowers that does not change appreciably over short time intervals. In partial contrast, shelf-sea pelagic deposits (in hundreds of meters of water) are affected more directly by short-term changes in bathymetry, salinity and oxygenation. The response of benthic communities to environmental shifts at the sea floor, therefore, is more pronounced in shelf-sea than in deep-sea settings. 